\title{
Surveillance of bacterial colonisation on contact surfaces in different medical wards
}

\author{
Karmen Godič Torkar and Sanja Ivić \\ Department for Sanitary Engineering, Faculty of Health Sciences, University of Ljubljana, Ljubljana, Slovenia
}

[Received in September 2016; Similarity Check in September 2016; Accepted in May 2017]

\begin{abstract}
This study was conducted to determine the bacterial colonization of some bacterial groups, including extended-spectrum $\beta$-lactamase (ESBLs) producers and methicillin-resistant Staphylococcus aureus (MRSA), on surfaces of the equipment and instruments in patient rooms and other workspaces in three different medical wards. The number of microorganisms on swabs was determined with the colony count method on selective microbiological mediums. The aerobic mesophylic microorganisms were found in $73.5 \%$ out of 102 samples, with the average and maximum values of $2.6 \times 10^{2}$ and $4.6 \times$ $10^{3}$ colony forming units (CFU) $100 \mathrm{~cm}^{-2}$, respectively. Members of the family Enterobacteriaceae, coagulase positive staphylococci, coagulase-negative staphylococci, and enterococci were detected in $23.4,31.4,53.2$, and $2.9 \%$ of samples, respectively. The differences in bacterial counts on the surfaces of the psychiatric, oncology, and paediatric wards were statistically significant $(P<0.001)$. About $40 \%$ out of 19 isolates from the family Enterobacteriaceae showed multiple resistance to three or more different groups of tested antibiotics, while ESBL was confirmed for only one strain. Staphylococci isolates were mostly resistant to penicillin. MRSA was confirmed in $5.2 \%$ of the tested S. aureus isolates. Greater attention should be paid to cleaning and the appropriate choice of disinfectants, especially in the psychiatric ward. Employees should be informed about the prevention of the spreading of nosocomial infections. Routine application of rapid methods for hygiene control of surfaces is highly recommended.
\end{abstract}

KEY WORDS: antibiotic susceptibility; bacterial contamination; hospitals; infections

Healthcare-acquired infections (HAIs) have been recognised as a critical problem affecting the quality of healthcare (1). The increasing emergence and spread of multiresistant bacteria in hospitals is a serious concern and continues to challenge infection control and hospital epidemiology practice worldwide (2). Gram-positive Clostridium difficile, methicillin-resistant Staphylococcus aureus (MRSA), vancomycin-resistant enterococci (VRE), and multidrug-resistant Gram-negative rods such as extended spectrum $\beta$-lactamase (ESBL)-producing Enterobacteriaceae, particularly Klebsiella pneumoniae, Escherichia coli, Enterobacter spp., Citrobacter spp., and Serratia spp., including Acinetobacter baumanii, share the ability to be shed from infected or colonised patients. One critical aspect of bacterial transfer is the ability of the microorganism to survive on various hospital surfaces for extended periods of time and the fact that it is difficult to eradicate it by cleaning and disinfection $(3,4)$. Pathogens contaminating environmental surfaces can spread to patients by direct contact with the surface or indirectly, typically on the hands of healthcare workers (5). Although hand hygiene is important in order to minimise the impact of this transfer, cleaning and disinfecting environmental surfaces appropriately is fundamental for reducing their potential

Correspondence to: Karmen Godič Torkar, Department for Sanitary Engineering, Faculty of Health Sciences, University of Ljubljana, Zdravstvena pot 5, SI-1000, Ljubljana, Slovenia. E-mail: karmen.torkar@zf.uni-lj.si contribution to the incidence of healthcare-associated infections (6).

In this study, we evaluated the level of contamination of surfaces in patient rooms and medical equipment in various medical wards with some main bacterial groups. We investigated the antibiotic resistance of isolated Enterobacteriaceae and staphylococci, including the determination of ESBL and MRSA bacterial strains.

\section{MATERIALS AND METHODS}

\section{Sampling}

The number and presence of individual groups of microorganisms on 17 selected surfaces of the equipment and supplies in patient rooms as well as in other clinical facilities in oncology, paediatric, and psychiatric medical wards was determined.

The samples were collected twice, in February 2014 and September 2014, to avoid the influence of daily and seasonal fluctuations in cleaning procedures and the number of microorganisms on the results. The samples were taken in the afternoons after the lunches have been served. One hundred and two (102) swabs with $10 \mathrm{~mL}$ of saline solution taken on $100 \mathrm{~cm}^{2}$ of selected surfaces were collected according to the international standard (7). The collecting 
points listed in Table 2 were identical in all three medical wards.

The evaluation of bacterial count and identification of isolates

The aerobic colony count (ACC), the number of Enterobacteriaceae (EB), coagulase-positive staphylococci (CPS), coagulase-negative staphylococci (CNS), and enterococci (EC) were determined in collected swabs using the standard plate count method. One $\mathrm{mL}$ of the bacterial suspension was transferred from the swab into a petri dish, and an appropriate medium was poured over it $(7,8)$.

The presence and number of aerobic mesophylic microorganisms were evaluated as ACC by counting the growing colonies on PCA agar after incubation under aerobic conditions at $30^{\circ} \mathrm{C}$ for 72 hours (Merck, Germany) (8).

The colonies of presumptive mannitol-positive staphylococci and mannitol-negative staphylococci were differentiated and counted on the Mannitol Salt Phenol Agar (Merck, Germany). After $48 \mathrm{~h}$ incubation at $37^{\circ} \mathrm{C}$, red or colourless colonies were produced by mannitol negative and presumptive coagulase-negative staphylococci. Small to large colonies with yellow zones were confirmed by inoculation on Baird Parker medium, supplemented with Rabbit Plasma Fibrinogene (RPF) (Biolife, Italy). Black colonies surrounded by white precipitation zones were presumed to be CPS $(9,10)$. Strain identification was performed using the detection of haemolytic activity, catalase and oxidase test, and biochemical characterisation with API Staph (bioMerieux, France) according to the manufacturer's instruction.

The enumeration of members of Enterobacteriaceae was carried out on MacConkey agar (Merck, Germany) after $24 \mathrm{~h}$ incubation at $35^{\circ} \mathrm{C}$ according to the standard (10, 11). Typical red (lactose-fermenters), colourless or pink (non-lactose fermenters) colonies were confirmed with Gram-stain microscopy, catalase and oxidase production, and biochemical tests API 10S (bioMerieux, France).

The presence and number of colonies of the genus Enterococcus were detected on KF Streptococcus Agar Base with TTC supplement (Merck, Germany) after $24 \mathrm{~h}$ incubation at $37{ }^{\circ} \mathrm{C}$ and confirmed on Bile Esculin Azide agar (Merck, Germany) (10).

The results were expressed as the number of colonyforming units (CFU) per $100 \mathrm{~cm}^{2}$ of sampled surfaces.

\section{Antibiotic susceptibility testing}

The antimicrobial susceptibility of 13 isolates from fam. Enterobacteriaceae and 46 isolates of staphylococci, obtained from the chosen surfaces were determined by using the Kirby-Bauer disc diffusion method. The control strains used to validate the antimicrobial susceptibility testing were Staphylococcus aureus ATCC 29213, Escherichia coli ATCC 25922, and K. pneumoniae ATCC 700603 (12).
The antibiotic discs for detecting the susceptibility of enterobacteria were cephalexin $(\mathrm{CN}-30 \mu \mathrm{g})$, tobramycin (NN-10 $\mu \mathrm{g}$ ), nalidixic acid (NA-30 $\mu \mathrm{g}$ ), ciprofloxacin (CIP$5 \mu \mathrm{g}$ ), and trimethoprime (TMP-5 $\mu \mathrm{g}$ ). The ESBL strains were confirmed using a combined disc diffusion test using cefotaxime (CTX-30), cefotaxime with clavulanate (CTX30/CA-10), ceftazidime (CAZ-30), ceftazidime with clavulanate (CAZ-30/CA-10), cefpodoxime (CPD-10 $\mu \mathrm{g})$, and cefpodoxime with clavulanate (CPD-10 $\mu \mathrm{g} / \mathrm{CA}-1 \mu \mathrm{g})$ (Mast Diagnostics, UK). MBLs were detected by combined disc test with imipenem and meropenem discs (10 $\mu \mathrm{g}$ each) (Mast Diagnostics, UK) alone and with $10 \mu \mathrm{L}$ of $0.5 \mathrm{~mol} \mathrm{~L}^{-1}$ EDTA $(\mathrm{pH}=8)$. An augmentation of the inhibition zone of $\geq 5 \mathrm{~mm}$ in the presence of clavulanate or EDTA pointed to the production of ESBL or MBLs (carbapenemases group), respectively (12).

The antibiotic discs for detecting the susceptibility of staphylococci were penicillin (P-10 EU), erythromycin (E-15), ciprofloxacin (CIP-5 $\mu \mathrm{g})$, clindamycin (CC-2 $\mu \mathrm{g}$ ), and kanamycin $(\mathrm{K}-30 \mu \mathrm{g})(\mathrm{BBL}$ Becton Dickinson, UK). Methicillin and vancomycin resistance was determined using the oxacillin and vancomycin E-test (AB Biodisk, Solna, Sweden), respectively (12).

\section{Production of inducible $\beta$-lactamases}

The presence of induced $\beta$-lactamases at the strains Staphylococcus and Enterobacteriaceae after exposure to penicillin and cefotaxime discs (BBL Becton Dickinson, UK) was also determined using a Cefinase (Cef-F) test with chromogenic cephalosporin (bioMerieux, France) (12).

\section{Genotypic detection of genes for $\beta$-lactamases at enterobacteria isolates}

The overnight cultures in BHI broth were centrifuged at $15,000 \times g$ for $15 \mathrm{~min}$. The supernatant was eliminated, and the pellet was resuspended in molecular biology-grade water and centrifuged at $15,000 \times g$ for $10 \mathrm{~min}$. After elimination of the supernatant, the pellet was resuspended in $40 \mu \mathrm{L}$ of molecular biology-grade water, subjected to boiling at $100{ }^{\circ} \mathrm{C}$ in a water bath for $10 \mathrm{~min}$, cooled on ice, and centrifuged at $15,000 \times g$ for $10 \mathrm{~s}$. Aliquots of $2 \mu \mathrm{L}$ of template DNA were used for PCR (13). The multiplex PCR with specific primers for $b l a_{\text {CTX-M }}$ groups $1,2,8,9$, and 25 was used. For detecting the variants from the families of $b l a_{\mathrm{VIM}}, b l a_{\mathrm{IMP}}$, as well as the variants $b l a_{\mathrm{GIM}}, b l a_{\mathrm{SPM}-1}$, and $b l a_{\mathrm{SIM}-1}$, multiplex primers $b l a_{\mathrm{MBL}}$ were used $(14,15)$. The primers and cycling conditions are shown in Table 1.

\section{Statistical analysis}

The programmes IBM SPSS Statistics 17 (2012) and Excel 2006 were used for statistical analysis of data. ANOVA was used for calculating the mean values, maximum and minimum values, standard deviations, while a t-test showed the statistical significance of differences between the mean values of microorganisms in medical 
Table 1 Oligonucleotide primers used for detecting $\beta$-lactamase genes

\begin{tabular}{|c|c|c|c|c|c|}
\hline $\begin{array}{c}\text { Target } \\
\text { sequence }\end{array}$ & $\begin{array}{l}\text { Nucleotide sequence } \\
\quad\left(5^{\prime} \rightarrow 3^{\prime}\right)\end{array}$ & Orientation & $\begin{array}{c}\text { Amplicon's } \\
\text { expected size (bp) }\end{array}$ & PCR conditions & Reference \\
\hline \multirow{2}{*}{$b l a_{\text {СтХ-м1 }}$} & $\begin{array}{c}\text { AAA AAT CAC TGC } \\
\text { GCC AGT TC }\end{array}$ & $\mathrm{F}$ & \multirow{2}{*}{415} & \multirow{20}{*}{$\begin{array}{c}94{ }^{\circ} \mathrm{C} / 5 \mathrm{~min} ; 30 \\
\text { cycles } 94{ }^{\circ} \mathrm{C} / 25 \mathrm{~s} \text {, } \\
52{ }^{\circ} \mathrm{C} / 40 \mathrm{~s}, \\
72{ }^{\circ} \mathrm{C} / 50 \mathrm{~s} ; \\
72{ }^{\circ} \mathrm{C} / 6 \mathrm{~min}(15)\end{array}$} & \multirow{10}{*}{ (15) } \\
\hline & $\begin{array}{c}\text { AGC TTA TTC ATC } \\
\text { GCC ACG TT }\end{array}$ & $\mathrm{R}$ & & & \\
\hline \multirow{2}{*}{$b l a_{\text {СТХ-М2 }}$} & $\begin{array}{c}\text { CGA CGC TAC CCC } \\
\text { TGC TAT T }\end{array}$ & $\mathrm{F}$ & \multirow{2}{*}{552} & & \\
\hline & $\begin{array}{c}\text { CCA GCG TCA GAT } \\
\text { TTT TCA GG }\end{array}$ & $\mathrm{R}$ & & & \\
\hline \multirow{2}{*}{$b l a_{\mathrm{CTX}-\mathrm{M} 8}$} & $\begin{array}{l}\text { TCG CGT TAA GCG } \\
\text { GAT GAT GC }\end{array}$ & $\mathrm{F}$ & \multirow{2}{*}{666} & & \\
\hline & $\begin{array}{c}\text { AAC CCA CGA TGT } \\
\text { GGG TAG C }\end{array}$ & $\mathrm{R}$ & & & \\
\hline \multirow{2}{*}{$b l a_{\text {СтХ-м9 }}$} & $\begin{array}{l}\text { CAA AGA GAG } \\
\text { TGC AAC GGA TG }\end{array}$ & $\mathrm{F}$ & \multirow{2}{*}{205} & & \\
\hline & $\begin{array}{c}\text { ATT GGA AAG CGT } \\
\text { TCA TCA CC }\end{array}$ & $\mathrm{R}$ & & & \\
\hline \multirow{2}{*}{$b l a_{\text {СТХ-м25 }}$} & $\begin{array}{c}\text { GCA CGA TGA CAT } \\
\text { TCG GG }\end{array}$ & $\mathrm{F}$ & \multirow{2}{*}{327} & & \\
\hline & $\begin{array}{c}\text { AAC CCA CGA TGT } \\
\text { GGG TAG C }\end{array}$ & $\mathrm{R}$ & & & \\
\hline \multirow{2}{*}{$b l a_{\mathrm{IMP}}$} & $\begin{array}{l}\text { GGA ATA GAG TGG } \\
\text { CTT AAT TCT C }\end{array}$ & $\mathrm{F}$ & \multirow{2}{*}{188} & & \multirow{10}{*}{$(14,15)$} \\
\hline & $\begin{array}{c}\text { CCA AAC CAC TAC } \\
\text { GTT ATC T }\end{array}$ & $\mathrm{R}$ & & & \\
\hline \multirow{2}{*}{$b l a_{\mathrm{VIM}}$} & $\begin{array}{c}\text { GAT GGT GTT TGG } \\
\text { TCG CAT A }\end{array}$ & $\mathrm{F}$ & \multirow{2}{*}{390} & & \\
\hline & $\begin{array}{c}\text { CGA ATG CGC AGC } \\
\text { ACC AG }\end{array}$ & $\mathrm{R}$ & & & \\
\hline \multirow{2}{*}{$b l a_{\mathrm{GIM}}$} & $\begin{array}{l}\text { TCG ACA CAC CTT } \\
\text { GGT CTG AA }\end{array}$ & $\mathrm{F}$ & \multirow{2}{*}{477} & & \\
\hline & $\begin{array}{c}\text { AAC TTC CAA CTT } \\
\text { TGC CAT GC }\end{array}$ & $\mathrm{R}$ & & & \\
\hline \multirow{2}{*}{$b l a_{\mathrm{SPM}}$} & $\begin{array}{l}\text { AAA ATC TGG GTA } \\
\text { CGC AAA CG }\end{array}$ & $\mathrm{F}$ & \multirow{2}{*}{271} & & \\
\hline & $\begin{array}{l}\text { ACA TTA TCC GCT } \\
\text { GGA ACA GG }\end{array}$ & $\mathrm{R}$ & & & \\
\hline \multirow{2}{*}{$b l a_{\mathrm{SIM}}$} & $\begin{array}{c}\text { TAC AAG GGA TTC } \\
\text { GGC ARC G }\end{array}$ & $\mathrm{F}$ & \multirow{2}{*}{570} & & \\
\hline & $\begin{array}{l}\text { TAA TGG CCT GTT } \\
\text { CCC ATG TG }\end{array}$ & $\mathrm{R}$ & & & \\
\hline
\end{tabular}

wards and between seasons. The rate of statistical significance was determined with value $P \leq 0.05$.

\section{RESULTS}

The level of surface contamination in medical wards

ACC and CNS were present in $73.5 \%$ and $53.2 \%$ out of 102 collected swabs, respectively. Enterobacteriaceae were present in only $26.6 \%$ of samples, mostly on surfaces of the psychiatric ward (Figure 1). The number of ACC exceeded the recommended values $\leq 250 \mathrm{CFU} 100 \mathrm{~cm}^{-2}$ for surfaces which were in contact with hands in patient rooms (17) in the psychiatric, paediatric, and oncology wards in $38.2 \%, 5.9 \%$, and $0 \%$ of samples, respectively.

The most frequently contaminated surfaces were those of telephone headsets, night tables, wheelchair handles, serving trays, bedside frames, and water taps (Table 2). The highest number of ACC with the average and maximum values of $2.6 \times 10^{2}$ and $4.6 \times 10^{3} \mathrm{CFU} 100 \mathrm{~cm}^{-2}$, respectively, was followed by the number of CNS and CPS (Figure 2). The contamination of surfaces was the highest in the psychiatric ward, while the lowest number of positive samples, as well as the lowest number of microorganisms, 


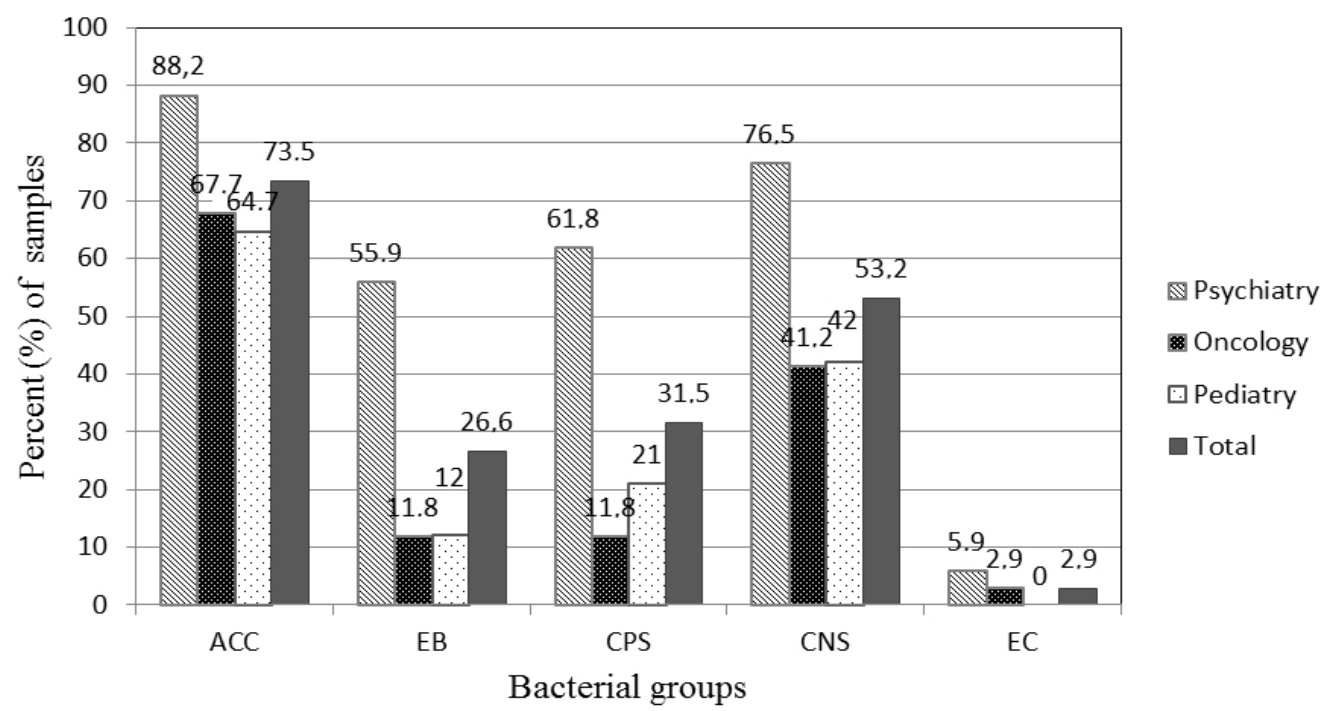

Figure 1 Percent (\%) of samples in which individual bacterial groups were detected ( $n=102$ samples). ACC: Aerobic colony count; EB: Enterobacteriaceae; CPS: Coagulase-positive staphylococci; CNS: Coagulase-negative staphylococci; EC: Enterococcus

were found on surfaces in the paediatric ward (Figure 1, Figure 2).

After biochemical identification, the most frequent isolates from the family Enterobacteriaceae were Serratia marcescens $(53.8 \%$ of isolates), Enterobacter aerogenes $(23.1 \%)$, Yersinia enterocolitica $(15.4 \%)$, and E. coli ( $7.7 \%)$. We also detected three representatives from the genus Pseudomonas.

Only 19 (41.3\%) out of 46 presumptive CPS strains were confirmed as $S$. aureus with biochemical tests, while others belonged to CNS S. caprae, S. warneri, S. hominis, S. epidermidis, S. capitis, and S. lugdunensis in 11 (23.9\%), $10(21.7 \%), 2(4.3 \%), 2(4.3 \%), 1(2.2 \%)$, and $1(2.2 \%)$ cases, respectively. Other CNS strains, which formed typical colonies on Mannitol Salt Phenol Agar, were not further identified.

\section{Susceptibility to antimicrobials}

The strains of Enterobacteriaceae were mostly resistant to nalidixic acid and trimethoprime, and were sensitive to meropenem, cefotaxime, and cephalexin (Table 3).

According to the combined disc diffusion method, there were differences between the diameters of the inhibition zones around one or more paired cephalosporin discs, exceeding $5 \mathrm{~mm}$ in one out of 13 strains. With this strain, which belonged to the genus Serratia, the PCR analyses confirmed the gene sequences from the group CTX-9 for ESBL. The production of presumptive MBLs was detected after the addition of EDTA to the discs in two (15.4\%) of the isolates; one of them was the strain, which was also positive for ESBL (Table 3). However, the genes of the tested groups of MBLs were not confirmed in any of these isolates.

About $95.7 \%$ out of 46 staphylococcal isolates were resistant to penicillin, 36 ( $78.3 \%$ ) of them showed a sharp edge zone around the penicillin discs. They were highly susceptible to ciprofloxacin, erythromycin, and clindamycin, while only half of the tested strains showed susceptibility to kanamycin with a high percentage of intermediate isolates (Table 3). Only one S. aureus and 2 CNS strains showed resistance to oxacillin with $\mathrm{MIC} \geq 4 \mu \mathrm{g} \mathrm{mL}^{-1}$ and $\geq 0.5 \mu \mathrm{gmL}^{-1}$, respectively (12). Two strains were obtained from the surfaces in the psychiatric ward and one of them from the oncology ward. Five (26.3\%) out of 19 S. aureus strains yielded resistance to amikacin, six strains (31.6\%) to erythromycin, four $(21.0 \%)$ to ciprofloxacin, and six strains $(31.6 \%)$ to clindamycin.

VRSA was not established as the MIC values were $\leq 8 \mu \mathrm{g} \mathrm{mL}^{-1}$ of vancomycin at all S. aureus strains (12).

With the cefinase test, we detected inducible $\beta$-lactamases in $10(76.9 \%)$ and $30(65.2 \%)$ of Enterobacteriaceae and Staphylococcus isolates, respectively.

\section{DISCUSSION}

On the tested surfaces of patient rooms, other clinical facilities, and the equipment of three medical wards, mostly aerobic mesophylic bacteria (ACC) were present, followed by CNS in about $53 \%$ of collected swabs. CPS and CNS represent part of normal human microflora on the skin, and they can be easily transferred by contact with surfaces (18). We have clearly demonstrated that the degree of environmental contamination with Gram-positive organisms was much more extensive in this environment than for Gram-negative microorganisms. It was confirmed that Gram-positive bacteria persist longer on surfaces than Gram-negative bacteria (19). Different materials also affected the adhesion of microorganisms. CNS persisted for 8-21 days on cotton, while Gram-negative P. aeruginosa lived for only 2-24 hours on the same surface. Neely and 
Maley (20) also reported that staphylococci and enterococci sometimes survive up to 90 days on common hospital materials, such as cotton, polyester, and propylene plastic. The common nosocomial pathogens survive longer on polyethylene and polyurethane surfaces than on cotton or blend surfaces $(19,20)$. Both groups often cause HAIs with a higher degree of antibiotic resistance (21).

Enterobacteriaceae and enterococci are indicator microorganisms for inadequate hygienic practice. The first group does not survive long on surfaces, while enterococci do (21). Enterobacteriaceae, which were present in $26.6 \%$ and Enterococci, detected in only $3 \%$ of our samples, were both present mostly on surfaces in the psychiatric ward (Figure 1, Table 2).

Statistically significant differences in the mean values of the bacterial count were calculated between the samples from the psychiatric ward and the other two wards, while the differences between the mean values of the number of microorganisms from the paediatric and oncology wards were not significant.

Significant differences in the bacterial count in the samples taken in February and in September were not observed. The lowest number of positive samples, as well as the lowest number of microorganisms on surfaces were found in the paediatric ward followed by the oncology ward (Figure 1, Figure 2). The number of ACC exceeded the recommended values $\leq 250 \mathrm{CFU} 100 \mathrm{~cm}^{-2}$ (17) most often in the psychiatric ward $(38.2 \%)$, while only $6 \%$ of the samples were inadequate in the paediatric ward. The number of ACC did not exceed the limits in any of the tested samples from the oncology ward.

Highly immunosuppressed patients are hospitalised in both, paediatric and oncology wards. Children with cancer are also hospitalised in the paediatric ward. Overall, patients spend longer periods in the oncology ward than in the paediatric ward, but some of them return for several shorter therapies. Psychiatric hospitalisations are usually long and re-occurring within the same institution. The highest contamination in the psychiatric ward by comparison with other two wards is probably due to the lower vigilance of staff at cleaning and disinfecting. They assume that patients are mostly not exposed to invasive surgery interventions that could lead to infections. Patients treated in this ward are in most cases not immunocompromised or do not suffer from any severe physical disease. They are also generally more mobile than those in the other two wards making the spread of microorganisms more intensive in the environment and their unwanted colonisation more frequent. Patients have an altered mental state and are often less capable of taking care of themselves or have difficulties in understanding the instructions for the proper maintenance of personal hygiene, with which they could prevent the transfer of microorganisms in their environment.

The guidelines of the National Committee for Hospital Infections (NAKOBO) (22) describe equal standard interventions in all medical wards emphasising hand disinfection, strict contact isolation, and sampling procedures for MRSA and ESBL screening tests. Samples

Table 2 The percent (\%) of the individual sampling points in all three clinical wards in which different groups of microorganisms $(n=102)$ were detected

\begin{tabular}{|c|c|c|c|c|c|}
\hline \multirow{2}{*}{ Sampling points } & \multicolumn{5}{|c|}{$\%$ of samples with individual goups of microorganisms } \\
\hline & $\mathrm{ACC}$ & EB & EC & KPS & CNS \\
\hline Telephone handsets & 100 & 33 & 0 & 33 & 33 \\
\hline Cuff for measuring blood pressure acc. RR & 67 & 33 & 0 & 33 & 33 \\
\hline Cart for ECG apparatus & 33 & 0 & 0 & 17 & 0 \\
\hline Wheelchair handle & 100 & 50 & 0 & 83 & 33 \\
\hline Medicines cart & 67 & 17 & 0 & 50 & 0 \\
\hline Serving tray & 83 & 33 & 17 & 50 & 17 \\
\hline Teapot handle & 83 & 33 & 0 & 67 & 50 \\
\hline Wardrobe for clean linen (inside) & 50 & 33 & 0 & 33 & 50 \\
\hline Tray trolley for clean linen & 50 & 17 & 0 & 33 & 17 \\
\hline Basket for dirty laundry & 83 & 0 & 0 & 50 & 50 \\
\hline Bedside frames & 67 & 33 & 17 & 67 & 33 \\
\hline Bathroom sink & 83 & 33 & 0 & 50 & 33 \\
\hline Water tap (ESBL room) & 83 & 17 & 17 & 67 & 33 \\
\hline Night table & 100 & 33 & 0 & 100 & 50 \\
\hline Apparatus for adjusting bed backrest & 67 & 17 & 0 & 67 & 50 \\
\hline Door handles (ESBL room) & 67 & 0 & 0 & 33 & 0 \\
\hline Bed lining (ESBL room) & 83 & 17 & 0 & 67 & 50 \\
\hline
\end{tabular}

ACC: Aerobic colony count; EB: Enterobacteriaceae; CPS: Coagulase-positive staphylococci; CNS: Coagulase-negative staphylococci; $E C$ : Enterococcus 


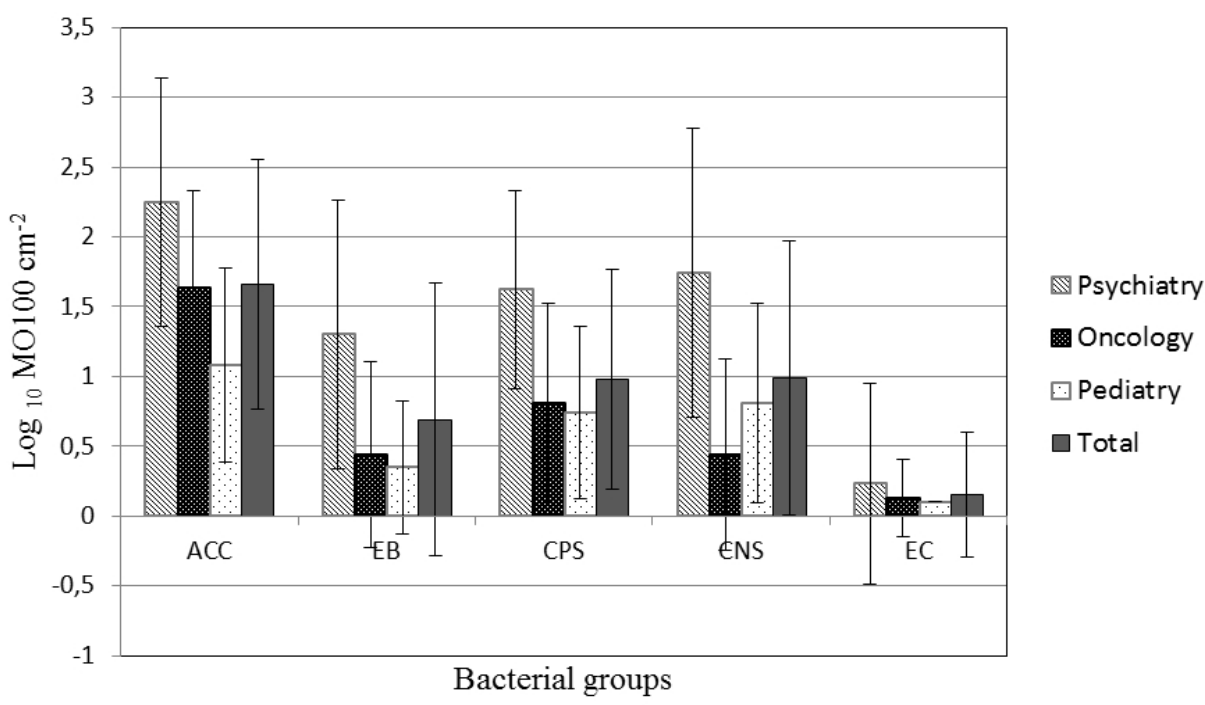

Figure 2 The number of different groups of microorganisms on surfaces in individual medical wards. ACC: Aerobic colony count; EB: Enterobacteriaceae; CPS: Coagulase-positive staphylococci; CNS: Coagulase-negative staphylococci; EC: Enterococcus; MO: Microorganisms

for screening are taken within 48 hours of admission to the hospital from every patient. Furthermore, controlling MRSA and ESBL infection in a psychiatric ward is specific. The contact isolation - although sometimes needed because of bacteria with multiple resistance, may cause deterioration of a patient's mental disorder. Therefore Vuga et. al. (2013) (23) recommended that specific guidelines for taking screening samples in psychiatric ward settings should be prepared.

In the psychiatric ward, greater attention should also be paid to cleaning and the appropriate choice of disinfectants. They should verify the presence of microorganisms on the hands of patients and staff. Employees should be additionally instructed about the prevention against the spreading of nosocomial infections. The routine application of rapid methods for hygiene control of surfaces is highly recommended.

In all medical wards, routine room cleaning is carried out regularly each morning and, if necessary, additionally in late afternoon according to the NAKOBO guidelines (22). In our study, the samples were not collected immediately after morning cleaning, but rather in the early afternoon, because we wished to verify not only the adequacy of cleaning but also the bacterial contamination occurring during the day. Nurses, employed in each ward, are responsible for cleaning and disinfection of the surfaces in direct contact with patients, while other equipment and sanitary facilities are cleaned by housekeepers or cleaning service staff. The type of disinfectant is prescribed specifically for individual wards (22). Additional disinfection with aerosols of orthophosphoric acid, hydrogen peroxide, and silver cations takes place in patient rooms in the paediatric and oncology wards (24), which results in lower contamination of surfaces, but according to Steinberg et al.
(5) this does not always eliminate the risk of acquisition of pathogens from the environment.

Telephone headsets, night tables, wheelchair handles, serving trays, bedside frames, and water taps were the most contaminated surfaces tested in the study (Table 2). AlHamad and Maxwell (2008) (25) also reported that bed frames, telephones, and computer keyboards were the surfaces that yielded a high total viable count. The surfaces inside the patients' rooms (patients area) were (except the night tables) less contaminated than those in the common area of the medical ward, which was the case in our study as well.

ACC was determined in all six samplings on telephone handsets, wheelchair handles, and night table surfaces; CPS were also common on the last two mentioned objects. Brady et al. (26) studied the bacterial contamination of 70 bedcontrol handsets. He determined that $67(95.7 \%)$ of them demonstrated bacterial growth with an average log $1.5 \mathrm{CFU}$. The handsets were contaminated in our study in $67 \%$ of cases with average log 1.6 CFU. Staphylococcus aureus (94.3\%), MRSA (in $12.9 \%$ ), Enterococcus spp. (in $41.3 \%$ ), Bacillus (in $5.7 \%$ ), and coliforms (in $2.9 \%$ ) of samples were mostly recognised on tested surfaces. He concluded that patients and medical and nursing staff commonly touch hospital bed-control handsets and they are relatively permanently attached to the bed frames of all inpatient beds. In our case, this is true also for surface bedside tables (Table 2 ). These characteristics suggest their use as a potential marker of general healthcare environmental contamination (26).

In our study, the presence of enterococci on serving trays indicated the improper washing and cleaning of the trays or inadequate hygiene by the staff delivering the meals. It is of great concern that they were also found on the water taps in the isolation rooms with ESBL positive patients 
(Table 2). Neely and Maley (20) and John (27) reported that some microbes, for example, $P$. aeruginosa survived for months or longer in a wet environment, but only for a few hours to a few days on dry surfaces. We also identified three representatives from the genus Pseudomonas, isolated from the toilet sink in the psychiatric ward.

In our experiment, wet surfaces (water taps) were more contaminated, including with $P$. aeruginosa. Similar results were obtained by De Abreu et al. (28), where P. aeruginosa was repeatedly isolated from sinks and taps in different medical wards in a major hospital in Portugal.

We share the view of Pereira da Fonseca et al. (2016) (29) that strict standards of infection control in hospitals and increased public education about hand hygiene, routine schedules of cleaning, sanitising, and disinfecting are recommended to decrease the risk of transmission in hospitals among patients.

The results of Lemmen et al. (21) indicate that the inanimate environment of patients colonised or infected with multi-resistant bacteria becomes frequently contaminated, and therefore surfaces and objects may very likely serve as a secondary reservoir for cross-transmission.
One of the major reasons that these organisms survive in the hospital environment is their intrinsic resistance to several commonly used antibiotics and, perhaps more importantly, their ability to acquire resistance to all currently available antibiotics, either by mutation or by receipt of foreign genetic material through the transfer of plasmids and transposons (30). In the second Slovenian national HAIs prevalence survey, conducted within the European point prevalence survey of HAIs and antimicrobial use in acutecare hospitals, 5628 patients were included. About 3.8\% of patients had at least one HAI and additional $2.6 \%$ were still being treated for HAIs on the day of the survey; the prevalence of HAIs was $6.4 \%$. The prevalence of urinary tract infections was the highest $(1.4 \%)$, followed by pneumoniae $(1.3 \%)$, and surgical site infections $(1.2 \%)$ (31).

The strains from the fam. Enterobacteriaceae, isolated from examined surfaces in three medical wards, belonged mostly to Serratia marcescens (53.8\% of isolates), Enterobacter aerogenes (23.1\%), Yersinia enterocolitica (15.4\%), and E. coli $(7.7 \%)$. S. marcescens represents an important cause of HAIs, especially in neonatal intensive

Table 3 Susceptibility of the tested isolates from the Enterobacteriaceae family $(n=13)$ and genus Staphylococcus ( $n=46)$ using the disc diffusion method and combination disc diffusion test for confirming ESBL production

\begin{tabular}{|c|c|c|c|c|c|c|c|c|c|}
\hline \multirow{2}{*}{$\begin{array}{l}\text { Antimicrobial } \\
\text { agent }\end{array}$} & \multicolumn{3}{|c|}{$\begin{array}{l}\text { Disc diffusion } \\
\text { breakpoints }\end{array}$} & \multicolumn{2}{|c|}{$\%$ of strains } & \multicolumn{4}{|c|}{$\begin{array}{l}\text { Combined disc diffusion method } \\
\text { inh. cone ( }(\mathrm{mm})\end{array}$} \\
\hline & $\mathbf{S}$ & I & $\mathbf{R}$ & $\mathbf{S}$ & $\mathbf{I}$ & $\mathbf{R}$ & Range & Mean & $\begin{array}{l}\% \\
\geq 5^{\mathrm{c}}\end{array}$ \\
\hline \multicolumn{10}{|l|}{ Enterobacteriaceae } \\
\hline Cephalexin $^{\mathrm{d}}$ & $\geq 14$ & & $<14$ & 53.8 & 0 & 46.2 & $6-30$ & 16.1 & \\
\hline Ceftazidime & $\geq 21$ & $18-20$ & $\leq 17$ & 38.5 & 15.4 & 46.2 & $6-34$ & 15.7 & \\
\hline Ceftazidime/CA ${ }^{\mathrm{a}}$ & & & & 38.5 & 15.4 & 46.2 & $6-35$ & 16.1 & 0 \\
\hline Cefotaxime & $\geq 26$ & $23-25$ & $\leq 22$ & 23.1 & 23.1 & 53.8 & $6-30$ & 17.2 & \\
\hline Cefotaxime $/ \mathrm{CA}^{\mathrm{a}}$ & & & & 38.5 & 7.7 & 53.8 & $6-32$ & 17.5 & 0 \\
\hline Cefpodoxime & $\geq 21$ & $18-20$ & $\leq 17$ & 23.1 & 7.7 & 69.2 & $6-25$ & 12.9 & \\
\hline Cefpodoxime/CA ${ }^{\mathrm{a}}$ & & & & 23.1 & 7.7 & 69.2 & $6-28$ & 13.4 & 7.7 \\
\hline Ciprofloxacin & $\geq 21$ & $16-20$ & $\leq 15$ & 38.5 & 30.8 & 30.8 & $6-29$ & 17.2 & \\
\hline Meropenem & $\geq 23$ & $20-22$ & $\leq 19$ & 53.8 & 0 & 46.2 & $8-32$ & 19.1 & \\
\hline Meropenem/EDTA & & & & 53.8 & 0 & 46.2 & $8-34$ & 19.4 & 15.4 \\
\hline Imipenem & $\geq 23$ & $20-22$ & $\leq 19$ & 46.2 & 7.7 & 46.2 & $8-33$ & 19.3 & \\
\hline Imipenem/EDTA & & & & 53.8 & 0 & 46.2 & $8-33$ & 19.3 & 7.7 \\
\hline Nalidixic acid & $\geq 19$ & $14-18$ & $\leq 13$ & 30.8 & 0 & 69.2 & $28-40$ & 34.8 & \\
\hline Tobramycin & $\geq 17$ & & $\leq 14$ & 69.2 & 0 & 30.8 & $31-41$ & 37.9 & \\
\hline Trimethoprim & $\geq 18$ & & $\leq 15$ & 15.4 & 30.8 & 53.8 & $6-25$ & 10.3 & \\
\hline \multicolumn{10}{|l|}{ Staphylococcus } \\
\hline Benzyl penicilin & $\geq 29$ & - & $\leq 28$ & 4.3 & 0 & 95.7 & $6-11$ & 6.7 & \\
\hline Ciprofloxacin & $\geq 21$ & $16-20$ & $\leq 15$ & 91.3 & 2.2 & 6.5 & $6-40$ & 27.2 & \\
\hline Clindamycin & $\geq 21$ & $15-20$ & $\leq 14$ & 84.8 & 6.5 & 8.7 & $6-42$ & 27.2 & \\
\hline Erythromycin & $\geq 23$ & $14-22$ & $\leq 13$ & 80.4 & 6.5 & 13.0 & $6-40$ & 26.5 & \\
\hline Kanamycin $^{\mathrm{d}}$ & $\geq 18$ & $14-17$ & $\leq 13$ & 50.0 & 45.7 & 4.3 & $6-32$ & 19.0 & \\
\hline
\end{tabular}

${ }^{a} C A$, clavulanic acid; ${ }^{b}(12) ; S$, susceptible; I, intermediate; $R$, resistant; ${ }^{c}$ percent (\%) of strains, where there was a difference between the zone diameters of either of the antibiotic discs and their respective antibiotic/CA or /EDTA discs $\geq 5 \mathrm{~mm} ;{ }^{d}(16)$ 
care units (32). Ivanova et al. (33) reported that $S$. marcescens was also found in the environment in their hospital, particularly on nurses' hands, suggesting transmission by staff handling.

In our study, $40 \%$ of isolates from the family Enterobacteriaceae showed multiple resistance to three or more different groups of tested antibiotics. Hauser (34) found out that the strains of Enterobacter, Serratia, Citrobacter, Providencia, and Morganella spp. were mostly sensitive to quinolones (e.g. ciprofloxacin) and sulpha drugs (e.g. sulfamethoxazole in combination with trimethoprim), the fourth generation of cephalosporins (cefepine) and amino-glicosydes tobramycin, gentamycin, and amikacin. Carbapanems are often effective as well, while the thirdgeneration cephalosporins (e.g. cefotaxime) should not be used to treat infections caused by these bacteria $(34,35)$. The isolates from the surfaces of our medical wards also showed higher sensitivity to carbapenems (about $54 \%$ ) and tobramycin (69\%) but not to trimethoprim (15\%). A higher proportion of intermediate susceptibility to trimethoprim and to ciprofloxacin $(30.8 \%)$ was also detected. The resistance of $S$. marcescens strains to tobramycin (11\%) was similar to the data (7.1\%) published by Mahlen (36). Inducible $\beta$-lactamases were found, using a cefinase test, in $73 \%$ of all tested strains, which is in correlation with their apparent resistance to $\beta$-lactam antibiotics (Table 3). ESBL production was detected with a combined disc test in $26.6 \%$ of strains, but the ESBL type CTX-9 was confirmed with chosen primers in only one $S$. marcescens isolate $(6.7 \%)$. Some other studies show that $S$. marcescens strains most commonly carry CTX-M-type ESBLs, particularly bla $a_{\text {CTX-1 }}$ bla $a_{\text {CTX-3 }}$ bla $a_{\text {CTX-9 }}$, bla $a_{\text {CTX-15 }}(33,37,38)$. The members of Enterobacteriaceae, including Serratia spp. and Enterobacter spp., to which most of our isolates belonged, carry a chromosomal ampC gene. AmpC $\beta$-lactamases inactivate a wide variety of $\beta$-lactam antibiotics and are not inhibited by clavulanic acid $(36,39)$. The molecular characterisation of our isolates for these sequences has not yet been performed. All Serratia species are also intrinsically sensitive to carbapenems, although some $S$. marcescens strains that harbour chromosomal carbapenemases have been identified (36). Plasmid-borne class B MBLs, including IMP-type variants and VIM-2, have been identified in $S$. marcescens (40). Bla $a_{\mathrm{VIM}-1}$ gene was also detected in the representatives of the genus Enterobacter (41). With the combined disc method, we found only one presumptive strain producer of carbapenemases, but it was not confirmed by PCR with the chosen primer.

Invasive staphylococcal infections constitute a public health problem and a therapeutic challenge (42). In addition to Staphylococcus aureus, CNS are becoming significant as the causative agents of hospital-acquired infections, which are often associated with multiple antimicrobial resistance mechanisms including, in particular, methicillin resistance $(43,44)$. CNS in Europe were resistant to penicillin in 91 to $96 \%$ clinical isolates, to erythromycin in 67 to $72 \%$, to clindamycin in 33 to $67 \%$, to ciprofloxacin in $79 \%$, and to vancomycin in $0 \%$ (42). Our results show similar resistance of staphylococci, including $S$. aureus, to penicillin and higher susceptibility to almost all other tested antibiotics. These data are comparable with reports of the skin isolates' susceptibility from the Central Slovenia region published by Švent-Kučina et al. (45) and the isolates from the nasal mucosa of medical students in Japan (46). ŠventKučina et al. (45) also reported about $2.8 \%$ of MRSA strains, which is slightly lower than the results of our study $(5.2 \%)$ and the results obtained by other authors $(6.9 \%)$ (25) (Table 3).

The penicillin disc zone edge and cefinase tests were positive for $\beta$-lactamase production at $78.3 \%$ and $65.2 \%$ of isolates, respectively. Regardless of the $95.7 \%$ resistance to penicillin in the tested strains, we can assume that the methods are not sensitive enough, as was also noted in previous studies $(47,48)$.

More samples should be collected during different seasons in future experiments for a better understanding of bacterial transmission and survival on the surfaces of medical wards. For the determination of the number and presence of individual bacterial species we used conventional culture techniques including biochemical tests, which are the limitations of our study. Therefore, we did not provide such accurate results as those enabled by the use of different PCR techniques, like illumina massively parallel sequencing approach of the 16S rRNA genes (29).

\section{CONCLUSIONS}

The aerobic colony count and coagulase-negative staphylococci were in our study most often found on the surfaces of wheelchair handles, telephone handsets, and night tables in medical wards.

The percentage of contaminated sampled surfaces was the highest in the psychiatric ward. We recommend more attention to washing hands, cleaning, and disinfecting of equipment surfaces and instruments, proper laundering, food preparation and delivery, and education of staff as well as patients and visitors.

It was a matter of concern that $40 \%$ of the isolates from the fam. Enterobacteriaceae showed multiple resistance to the tested antibiotics, while MRSA was rare.

The hospital environment is contaminated by a variety of pathogenic and nonpathogenic multiple resistant bacteria that can persist on surfaces for prolonged periods. The hands and gloves of healthcare workers readily acquire pathogens after contact with contaminated hospital surfaces and they can subsequently transfer these organisms to patients and inanimate surfaces. For these reasons, hospitals must prepare a strategy for cleaning and disinfection in the wards, as well as the guidelines for reducing the risk of transmission of pathogens via contaminated hospital surfaces and 
medical equipment for healthcare and medical personnel according to the recommendations of the World Health Organization (WHO) and Centers for Disease Control and Prevention (CDC).

The data obtained in our study can give us useful information about the particularities of transmission ways of microorganisms in different medical wards. Strict and regular monitoring using rapid tests for hygiene quality of surfaces, necessarily supplemented with classical microbiological methods should be implemented.

\section{Acknowledgements}

The authors of the study would like to thank the management of the hospitals for permission to conduct the experiment in their wards. Special thanks goes to healthcare personnel for their assistance and help with sampling.

\section{Conflict of interest}

The authors declare no conflicts of interest.

\section{Abbreviations}

HAIs: healthcare-acquired infections; MRSA: methicillin-resistant Staphylococcus aureus; VRE: vancomycin-resistant enterococci; ESBL: extended spectrum $\beta$-lactamase; ACC: aerobic colony count; EB: Enterobacteriaceae; CPS: coagulase-positive staphylococci; CNS: coagulase-negative staphylococci; EC: enterococci; CFU: colony forming units; MBL: metallo-beta-lactamase

\section{REFERENCES}

1. Aly NY,Al-Mousa HH,Al Asar el SM. Nosocomial infections in a medical-surgical intensive care unit. Med Princ Pract 2008;17:373-7. doi: 10.1159/000141500

2. World Health Organization. Media Centre. Antimicrobial resistance, 2016 [displayed 10 February 2017]. Available at http://www.who.int/mediacentre/factsheets/fs194/en/

3. Bradford PA. Extended-spectrum $\beta$-lactamases in the $21^{\text {st }}$ century: characterization, epidemiology, and detection of this important resistance threat. Clin Microbiol Rev 2001;14:93351. doi: 10.1128/CMR.14.4.933-951.2001

4. Judge C, Galvin S, Burke L, Thomas T, Humphreys H, Fitzgerald-Hughes D. Search and you will find: detecting extended-spectrum $\beta$-lactamase-producing Klebsiella pneumoniae from a patient's immediate environment. Infect Control Hosp Epidemiol 2013;34:534-6. doi: 10.1086/670206

5. Steinberg JP, Denham ME, Zimring C, Kasali A, Hall KK, Jacob JT. The role of the hospital environment in the prevention of healthcare-associated infections by contact transmission. HERD 2013;7(Suppl 1):46-73. doi: $10.1177 / 193758671300701$ S06

6. Kampf G, Kramer A. Epidemiologic background of hand hygiene and evaluation of the most important agents for scrubs and rubs. Clin Microbiol Rev 2004;17:863-93 doi: 10.1128/CMR.17.4.863-893.2004

7. ISO 18593:2004 - Microbiology of food and animal feeding stuffs - Horizontal methods for sampling techniques from surfaces using contact plates and swabs. International Organization for Standardization, 2004.

8. ISO 4833-1:2013 - Microbiology of the food chain -Horizontal method for the enumeration of microorganisms - Part 1: Colony count at 30 degrees $\mathrm{C}$ by the pour plate technique. International Organization for Standardization, 2013.

9. ISO 6888-2:1999 - Microbiology of food and animal feeding stuffs - Horizontal method for the enumeration of coagulasepositive staphylococci (Staphylococcus aureus and other species) - Part 2: Technique using rabbit plasma fibrinogen agar medium. International Organization for Standardization, 1999.

10. Merck. Microbiology Manual. $12^{\text {th }}$ ed. [displayed 31 July 2016]. Available at http://www.analytics-shop.com/media/ Hersteller/Kataloge/millipore-de/Merck_Microbiology_ Manual_12th_edition.pdf

11. ISO 21528-2:- 2004 - Microbiology of food and animal feeding stuffs - Horizontal methods for the detection and enumeration of Enterobacteriaceae - Part 2: Colony-count method. International Organization for Standardization, 2004.

12. Clinical and Laboratory Standards Institute. M100-S25 Performance Standards for Antimicrobial Susceptibility Testing; Twenty-Fifth International Supplement [displayed 31 August 2016]. Available at http://www.ssu.ac.ir/cms/ fileadmin/user_upload/Moavenatha/MDarman/omuor_ azmayeshgahha/CLSI 2015.pdf

13. Queipo-Ortuño MI, Colmenero J De D, Macias M, Bravo MJ, Morata P. Preparation of bacterial DNA template by boiling and effect of immunoglobulin $\mathrm{G}$ as an Inhibitor in real-time PCR for serum samples from patients with brucellosis. Clin Vaccine Immunol 2008;15:293-6. doi: 10.1128/CVI.00270-07

14. Ellington MJ, Kistler J, Livermore DM, Woodford N. Multiplex PCR for rapid detection of genes encoding acquired metallo- $\beta$-lactamases. J Antimicrob Chemother 2007;59:3212. doi: $10.1093 / \mathrm{jac} / \mathrm{dkl} 481$

15. Woodford N. Rapid characterization of $\beta$-lactamases by multiplex PCR. Methods Mol Biol 2010;642:181-92. doi: 10.1007/978-1-60327-279-7_14

16. The European Committee on Antimicrobial Susceptibility Testing. Breakpoint tables for interpretation of MICs and zone diameters. Version 6.0, valid from 2016-01-01 [displayed 16 August 2016]. Available at http://www.eucast. org/fileadmin/src/media/PDFs/EUCAST_files/Breakpoint_ tables/v 6.0 Breakpoint table.pdf

17. University of Ljubljana, Medical Faculty, Institute for Microbiology and Immunology. Smernice za vzorčenje zraka in površin v operacijskih dvoranah, 2016 [The guidelines for air sampling and surfaces in operating rooms, in Slovenian] [displayed 10 February 2017]. Available at http://www.imi. si/dokumenti/SMERNICEZAVZORENJEZRAKAIN POVRINVOPERACIJSKIHDVORANAH.pdf

18. Marples RR, Richardson JF, Newton FE. Staphylococci as part of the normal flora of human skin. J Appl Bacteriol Symp 1990;69(Suppl 19):93S-99S. doi: 10.1111/j.1365-2672.1990. tb01801.x

19. Otter JA, Yezli S, French GL. The role played by contaminated surfaces in the transmission of nosocomial pathogens. Infect Control Hosp Epidemiol 2011;32:687-99. doi: 10.1086/660363 
20. Neely A, Maley MP. Survival of Enterococci and Staphylococci on hospital fabrics and plastic. J Clin Microbiol 2000;38:724-6. PMCID: PMC86187

21. Lemmen SW, Häfner H, Zolldann D, Stanzel S, Lütticken R. Distribution of multi-resistant Gram-negative versus Gram-positive bacteria in the hospital inanimate environment. J Hospital Infect 2004;56:191-7. doi: 10.1016/j. jhin.2003.12.004

22. NAKOBO, National Committee for Hospital infections, Working group of Ministry of Health Republic of Slovenia. Čiščenje in raskuževanje prostorov, opreme in pripomočkov ter minimalni tehnični pogoji za bolnišnice in druge zdravstvene ustanove, 2009[Guidelines for cleaning and disinfection procedures of facilities, equipment and utilities, and minimum technical requirements for hospitals and other medical institutions, in Slovenian] [displayed 15 February 2017]. Available at http://www.mz.gov.si/fileadmin/mz.gov. si/pageuploads/mz_dokumenti/delovna_podrocja/ zdravstveno_varstvo/zdravstveno_varstvo_v_posebnih/ NAKOBO_september_2010/MZ_pog1_9_Ciscenje_in_ razkuzevanje 2009.pdf

23. Vuga N, Velušček M, Grmek Košnik I. Obvladovanje proti meticilinu odporne bakterije Staphylococcus aureus (MRSA) v psihiatričnih bolnišnicah [Controlling methicillin resistant Staphylococcus aureus (MRSA) in psychiatric hospitals, in Slovenian]. In: Grmek Košnik I, Hvalič Touzery S, Skela Savič B, editors. Okužbe, povezane z zdravstvom Zbornik prispevkov z recenzijo. 4. simpozij Katedre za temeljne vede; 15 October 2013.; Kranj, Slovenia. Jesenice: Visoka šola za zdravstveno nego; 2013. p. 125-32.

24. Vomš S, Malik K. Razkuževanje prostorov z aerosoli v UKC [Desinfection of the rooms in medical wards by aerosols in University Clinical Centre Ljubljana, in Slovenian]. Aktualno 2015;2:10-1.

25. Al-Hamad A, Maxwell S. How clean is clean? Proposed methods for hospital cleaning assessment. J Hosp Infect 2008;70:328-34. doi: 10.1016/j.jhin.2008.08.006

26. Brady RRW, Kalima P, Damani NN, Wilson RG, Dunlop MG. Bacterial contamination of hospital bed-control handsets in a surgical setting: A potential marker of contamination of the healthcare environment. Ann R Coll Surg Engl 2007;89:656-60. doi: 10.1308/003588407X209347

27. John LD. Nosocomial infections and bath water: any cause for concern? Clin Nurse Spec 2006;20:119-23. PMID: 16705280

28. De Abreu PM, Farias PG, Paiva GS, Almeida AM, Morais PV. Persistence of microbial communities including Pseudomonas aeruginosa in a hospital environment: a potential health hazard. BMC Microbiology 2014;14:118. doi: 10.1186/1471-2180-14-118

29. Pereira da Fonseca TA, Pessôa R, Felix AC, Sanabani SS. Diversity of bacterial communities on four frequently used surfaces in a large Brazilian teaching hospital. Int J Environ Res Pub Health 2016;13:152. doi: 10.3390/ijerph13020152

30. Noskin GA, Stosor V, Cooper I, Peterson LR. Recovery of vancomycin-resistant enterococci on fingertips and environmental surfaces. Infect Control Hosp Epidemiol 1995;16:577-81. PMID: 8568202

31. Klavs I, Kolman J, Lejko Zupanc T, Kotnik Kevorkijan B, Korošec A, Serdt M. The prevalence of and risk factors for healthcare-associated infections in Slovenia: results of the second national survey Slovenian. Zdr Varst 2016;55:239-47. doi: 10.1515/sjph-2016-0033

32. Dessì A, Puddu M, Testa M, Marcialis MA, Pintus MC, Fanos V. Serratia marcescens infections and outbreaks in neonatal intensive care units. J Chemother 2009;21:493-9. doi: 10.1179/joc.2009.21.5.493

33. Ivanova D, Markovska R, Hadjieva N, Schneider I, Mitov I, Bauernfeind A. Extended-spectrum $\beta$-lactamase-producing Serratia marcescens outbreak in a Bulgarian hospital. J Hosp Infect 2008;70:60-5. doi: 10.1016/j.jhin.2008.04.033

34. Hauser AR. Gram-negative bacteria. Chapter 11. In: Antibiotic basics for clinicians. The ABCs of choosing the right antibacterial agent. $2^{\text {nd }} e d$. Baltimore (MD): Lippincott Williams \& Wilkins; 2013. p. 121-8.

35. Arnold MS, Dempsey JM, Fishman M, McAuley PJ, Tibert C, Vallande NC. The best hospital practices for controlling methicillin-resistant Staphylococcus aureus on the cutting edge. Infect Cont Hosp Epidemiol 2002;23:69-75. doi: 10.1086/502009

36. Mahlen SD. Serratia infections: from military experiments to current practice. Clin Microb Rev 2011;24:755-91. doi: 10.1128/CMR.00017-11

37. Choi SH, Lee JE, Park SJ, Kim MN, Choo EJ, Kwak YG, Jeong JY, Woo JH, Kim NJ, Kim YS. Prevalence, microbiology, and clinical characteristics of extendedspectrum $\beta$-lactamase-producing Enterobacter spp., Serratia marcescens, Citrobacter freundii, and Morganella morganii in Korea. Eur J Clin Microbiol Infect Dis 2007;26:557-61. doi: 10.1007/s10096-007-0308-2

38. Eckert C, Gautier V, Arlet G. DNA sequence analysis of the genetic environment of various bla ${ }_{\text {СтX-M }}$ genes. J Antimicrob Chemother 2006;57:14-23. doi: 10.1093/jac/dki398

39. Jacoby GA. AmpC $\beta$-lactamases. Clin Microbiol Rev 2009;22:161-82. doi: 10.1128/CMR.00036-08

40. Yum JH, Yong D, Lee K, Kim HS, Chong Y. A new integron carrying VIM-2 metallo- $\beta$-lactamase gene cassette in a Serratia marcescens isolate. Diagn Microbiol Infect Dis 2002;42:217-9. doi: 10.1016/S0732-8893(01)00352-2

41. Heller I, Grif K, Orth D. Emergence of VIM-1-carbapenemaseproducing Enterobacter cloacae in Tyrol, Austria. J Med Microbiol 2012;61:567-71. doi: 10.1099/jmm.0.038646-0

42. Becker K, Heilmann C, Peters G. Coagulase-negative Staphylococci. Clin Microbiol Rev 2014;27:870-926. doi: 10.1128/CMR.00109-13

43. Norton TD, Skeete F, Dubrovskaya Y, Phillips MS, Bosco 3rd JD, Mehta SH. Orthopedic surgical site infections: analysis of causative bacteria and implications for antibiotic stewardship. Am J Orthop (Belle Mead NJ) 2014;43:E89-92. PMID: 24839634

44. Shittu A, Lin J, Morrison, D, Kolawole D. Identification and molecular characterization of mannitol salt positive, coagulase-negative staphylococci from nasal samples of medical personnel and students. J Med Microbiol 2006;55:317-24. doi: 10.1099/jmm.0.46072-0

45. Švent-Kučina N, Pirš M, Kofol R, Blagus R, Smrke D, Bilban M, Seme K. Molecular characterization of Staphylococcus aureus isolates from skin and soft tissue infections samples and healthy carriers in the Central Slovenia region. APMIS 2016;124:309-18. doi: 10.1111/apm.12509

46. Higuchi W, Hirokazu I, Iwao Y, Dohmae S, Saito K, Takano T, Otsuka T, Baranovich T, Endo C, Suzuki N, Tomiyama Y, Yamamoto T. Extensive multidrug resistance of coagulase- 
negative staphylococci in medical students. J Inf Chem 2007;13:63-6. doi: 10.1099/jmm.0.46072-0

47. Kaase M, Lenga S, Friedrich S, Szabados F, Sakinc T, Kleine B, Gatermann SG. Comparison of phenotypic methods for penicillinase detection in Staphylococcus aureus. Clin
Microbiol Infect 2008;14:614-6. doi: 10.1111/j.1469-0691.2008.01997.x

48. Papanicolas LE, Bell JM, Bastian I. Performance of phenotypic tests for detection of penicillinase in Staphylococcus aureus isolates from Australia. J Clin Microbiol 2014;52:1136-8. doi: 10.1128/JCM.03068-13

Raznolikost in odpornost bakterijske mikroflore na kontaktnih površinah v različnih kliničnih oddelkih

Ugotavljali smo število in prisotnost nekaterih bakterijskih skupin, vključno z ESBL in MRSA na površinah opreme in instrumentov $\mathrm{v}$ bolniških sobah in drugih delovnih prostorih $\mathrm{v}$ treh različnih kliničnih oddelkih. Število mikroorganizmov v brisih, odvzetih na izbranih površinah, smo določili z metodo štetja kolonij na selektivnih mikrobioloških gojiščih. Skupno število aerobnih mezofilnih mikroorganizmov smo našli v 73,5 \% od 102 vzorcev, s povprečnimi in najvišjimi vrednostmi 2,6 $\times 10^{2}$ in 4,6 $\times 10^{3} \mathrm{CFU} 100 \mathrm{~cm}^{-2}$. Predstavnike družine enterobakterij, koagulaza pozitivne stafilokoke, koagulaza negativne stafilokoke in enterokoke smo ugotovili v 23,4,31,4 53,2 in 2,9\% vzorcev. Stevilo mikroorganizmov na površinah v psihiatričnem oddelku se je statistično značilno $(P<0,001)$ razlikovalo od števila, dobljenega na vzorčenih površinah onkološkega in pediatričnega oddelka. Okoli 40 \% od 19 izolatov iz družine Enterobacteriaceae je bilo večkratno odpornih proti trem ali več različnim skupinam testiranih antibiotikov, medtem ko je bil kot ESBL potrjen le en sev. Osamljeni sevi stafilokokov so bili večinoma odporni proti penicilinu. MRSA je bil potrjen v 5,2\% sevov $S$. aureus. Zaposleni morajo večjo pozornost posvetiti pravilnemu umivanju rok, čiščenju in razkuževanju površin, instrumentov in opreme v bolniških sobah in tudi v drugih prostorih kliničnih oddelkov, zlasti to velja za psihiatrični oddelek. Priporočljiva je uporaba hitrih metod za ugotavljanje uspešnosti čiščenja površin. 